\title{
Analisa Brand Reputation Wisata Daerah Menggunakan Sentimen Data Twitter (Studi Kasus:Museum Sangiran Kabupaten Sragen)
}

\author{
Fendy Prasetyo Nugroho ${ }^{1)}$, Yoga Dwi Pambudi ${ }^{2)}$ \\ Magister Teknik Informatika, Universitas AMIKOM Yogyakarta \\ Jl. Ring Road Utara, Condong Catur, Sleman, Yogyakarta \\ fendy.nugroho@students.amikom.ac.id ${ }^{1)}$,yoga.pambudi@students.amikom.ac.id ${ }^{2)}$
}

\begin{abstract}
Abstrak
Sektor pariwisata terutama pariwisata daerah di Indonesia masih sangat kurang mendapatkan perhatian baik dari pengelolaan, promosi dan investasi pengembangan. Pada era globalisasi saat ini pemanfaatan teknologi informasi untuk memperkenalkan wisata daerah dapat memberikan pengaruh kepada banyak wisatawan domestik maupun mancanegara yang sama-sama ingin mengeksplor tempat-tempat baru sebanyak mungkin. Tidak hanya bagi wisatawan, kesempatan baru ini juga menjadi sasaran banyak pemodal yang melihat adanya pasar strategis baru. Museum Sangiran merupakan tempat wisata andalan di Kabupaten Sragen, Jawa Tengah yang menyimpan banyak sejarah perkembangan manusia purba dengan bukti-bukti fosil yang ditemukan disana. Salah satu sosial media yaitu twitter adalah sosial media opini yang berisikan pendapat, pikiran maupun kritikan dari para pengguna terhadap suatu hal yang bebas disampaikan. Pada penelitian ini berfokus pada opini yang muncul mengenai kondisi tempat wisata dan pelayanan di Kawasan wisata Museum Sangiran Kabupaten Sragen dengan menggunakan analisis sentimen data twitter. Harapan yang ingin dicapai pada penelitian ini adalah tingkat efektivitas opini masyarakat pada penggunaan sosial media twitter dalam mempengaruhi perkembangan wisata daerah khususnya Museum Sangiran. Dari hasil analisa yang dilakukan, opini masyarakat yang memanfaatkan media sosial twitter cukup berpengaruh untuk memperkenalkan pariwisata daerah dengan mengelompokkan opini menjadi tiga kategori yaitu opini positif, opini negatif dan opini netral.
\end{abstract}

Kata kunci:Twitter, Analisis Sentimen, Sangiran, Pariwisata, Opini

\section{PENDAHULUAN}

Peningkatan kualitas sumber daya masyarakat merupakan kenyataan yang harus diprioritaskan untuk dilakukan secara terencana, terarah, intensif, efektif dan efisien. Dengan memperioritaskan pembangunan sumber daya masyarakat melalui penguasaan teknologi serta melibatkan masyarakat dalam segala proses pengembangan teknologi, masyarakat diharapkan dapat lebih mengenal teknologi masa depan. Beralihnya dunia analog menuju digital menambah variasi dalam visualisasi sebuah karya. Perkembangan pengetahuan teknologi multimedia dan animasi saat ini juga semakin beragam dan akan terus berkembang dengan cepat karena mendapat perhatian khusus sebagai sebuah teknologi praktis dan difungsikan untuk meningkatkan promosi khususnya bidang pariwisata dan meningkatkan nilai investasi dengan baik. (Nugroho FP, 2017)

Museum Sangiran adalah sebuah situs purbakala berlokasi di Kecamatan Kalijambe, Kabupaten Sragen yang menyimpan banyak sejarah kehidupan makhluk prasejarah atau purba di muka bumi ini dan menjadi situs manusia purba terlengkap di Asia. Selain itu, Sangiran adalah situs terpenting yang tersedia saat ini untuk penelitian dan perkembangan berbagai macam bidang ilmu pengetahuan terutama untuk bidang antropologi, arkeologi, biologi, geologi, paleoantropologi, teknologi serta pengembangan bidang pariwisata dan peningkatan kemampuan ekonomi kreatif masyarakat dan investasi. Keberadaan Situs Sangiran di wilayah Kabupaten Sragen sangat bermanfaat untuk mempelajari kehidupan prasejarah karena dilengkapi hasil budaya manusia purba, fosil flora dan fauna purba beserta gambaran stratigrafinya dan fosil 
manusia purba yang terus dicari dan diteliti hingga kini. (Nugroho FP, 2017)

Pada penelitian (Rosanti dan Zam, 2017) promosi merupakan berbagai kegiatan yang dilakukan antar perusahaan atau lembaga untuk mengkomunikasikan manfaat dari produknya dan untuk meyakinkan pengunjung atau konsumen sasaran. Fungsi dari promosi adalah sebagai media komunikasi untuk meningkatkan, memperkenalkan, mengajak, dan memberikan informasi kepada masyarakat selaku target sasaran agar mengetahui dan memahami dari semua pesan-pesan yang disampaikan baik mengenai sebuah produk, barang atau jasa melalui berbagai macam media promosi. Terdapat dua macam media promosi yang biasa dilakukan dalam melakukan promosi yaitu, media promosi berbasis cetak dan media berbasis elektronik atau digital baik media digital dalam jaringan (daring) ataupun media digital luar jaringan (luring) (Kotler dan Amstrong, 2008).

Internet merupakan media yang saat ini sedang berkembang pesat, hal ini didukung dengan semakin bertambahnya jumlah pengguna internet di Indonesia. Menurut survey yang dilakukan oleh APJII (Asosiasi Penyelenggara Internet Indonesia) yang diterbitkan pada November 2016 tercatat 132,7 juta pengguna internet, $98,6 \%$ perilaku pengguna internet memanfaatkannya sebagai tempat menawarkan atau mencari barang dan jasa, sedangkan jenis konten yang paling diminati yaitu media sosisal mencapai $97,4 \%$. Pengguna twitter tercatat 7,2 juta atau 5,5\%. (Rosanti dan Zam, 2017).

Menurut (Mayfield, 2008) media sosial adalah mengenai bagaimana menjadi manusia seutuhnya. Manusia dapat menemukan informasi dan inspirasi lebih cepat dari sebelumnya. Ide-ide baru, layanan jasa, model bisnis dan teknologi muncul dan berkembang begitu cepat di media sosial. Peranan media sosial pada kehidupan masyarakat khususnya generasi muda sudah sangat melekat pada kegiatan sehari-hari. Pandangan atau penilaian masyarakat juga sangat mudah digiring melalui sebaran informasi dari sosial media padahal belum diketahui kebenaran informasi tersebut baik itu berupa informasi yang positif, negatif atau bermakna provokatif. Selain itu, pemasaran media sosial menawarkan kesempatan besar untuk pengusaha atau pengelola, usaha kecil, perusahaan menengah, dan perusahaan besar untuk membangun merek mereka, brand images atau brand reputation dan bisnis mereka (Gunelius, 2011).

Sentimen analisis merupakan sebuah studi komputasi yang berhubungan dengan pendapat dan berorientasi dengan pengolahan bahasa alami (Kumar \& Sebastian, 2012). Sedangkan menurut (Dave, dkk, 2003) memaparkan bahwa Sentimen adalah informasi tekstual yang berada di dalam web dan berisi tentang fakta dan opini. Sentimen merupakan pernyataan atau ungkapan subjektif masyarakat yang mencerminkan persepsi seseorang terhadap peristiwa atau kejadian.

(Liu, 2011) Dalam proses analisis sentimen pada twitter menggunakan cara pengambilan data dalam jumlah yang besar atau sering disebut dengan Crawling data. Crawling data adalah proses pengambilan sejumlah besar halaman web dengan cepat ke dalam suatu tempat penyimpanan lokal dan mengindeksnya berdasar sejumlah kata kunci. Hal ini sangat membantu dalam penelitian untuk mendapatkan data besar secara daring.

Analisis sentimen pada twitter diambil menggunakan twitter crawler otomatis pada opini-opini yang diambil langsung dari halaman twitter. Hasil dalam analisis sentimen akan mendapatkan presepsi masyarakat terhadap kualitas pelayanan di Museum Sangiran. Selanjutnya dari perolehan data akan dilakukan klasifikasi untuk mengelompokkan pendapat masyarakat ke dalam tiga kategori yaitu opini positif, opini negatif dan opini netral. Menurut (Adam, dkk., 2002) menerangkan bahwa klasifikasi memiliki dua proses yaitu membangun model klasifikasi dari sekumpulan kelas data yang sebelumnya sudah didefinisikan (training data set) dan model tersebut digunakan untuk klasifikasi tes data serta mengukur akurasi dari model.

Dalam rangka membangun minat wisatawan untuk mengunjungi Museum Sangiran Kabupaten Sragen maka, pada penelitian ini memiliki tujuan untuk mengukur pandangan serta interaksi terhadap produk wisata yang ditawarkan kepada masyarakat luas melalui sosial media twitter dengan analisis data menggunakan sentimen data twitter yang telah di klasifikasikan. Selain itu, Melalui penelitian ini juga diharapkan dapat diperoleh gambaran yang 
jelas tentang bagaimana strategi promosi yang dilakukan Museum Sangiran melalui penggunaan sosial media twitter sebagai media promosi dalam menginformasikan, mempengaruhi dan mengingatkan pasar sasaran atas pelayanan dan fasilitas untuk pengunjung Sangiran.

\section{METODE PENELITIAN}

Dalam menyelesaikan penelitian ini dilakukan secara sistematis dengan tahapantahapan metodologi sebagai berikut:

a. Studi Pustaka

Penelitian dilakukan dengan melakukan studi kepustakaan, dengan mengumpulkan beberapa bahan referensi yang terkait dengan penelitian, baik melalui buku, artikel paper, jurnal, makalah dan mengunjungi beberapa situs yang terdapat di initernet terkait dengan analisis sentimen data twitter dan Museum Sangiran Kabupaten Sragen.

\section{b. Pengumpulan Data}

Pada tahap pengumpulan data ini dilakukan pengambilan data mengenai segala bentuk informasi yang berkaitan dengan informasi Museum Sangiran secara khusus melalui sosial media twitter. Proses pengambilan data yang digunakan dalam penelitian ini dilakukan dengan tiga metode yaitu metode wawancara, metode observasi dan metode dokumentasi.

\section{c. Klasifikasi Data}

Pada penelitian ini, data yang telah diperoleh kemudian diklasifikasikan untuk dapat dilakukan analisis lebih lanjut mengenai klasifikasi opini yang dibagi dalam tiga kategori yaitu opini positif, opini negatif dan opini netral yang menghasilkan kesimpulan dari pemanfaatan twitter sebagai media promosi untuk menarik minat pengunjung pada Museum Sangiran Kabupaten Sragen.

\section{d. Kesimpulan}

Tahapan akhir dari penelitian yang dilakukan ini yaitu penyampaian kesimpulan atas hasil dari penelitian dan analisis yang telah dilakukan dan pemberian saran dan ide untuk penelitian yang akan dilakukan pada periode berikutnya di Museum Purbakala Sangiran Kabupaten Sragen.

\section{TINJAUAN PUSTAKA}

(Bifet \& Frank, 2010) menyatakan bahwa Microblogging adalah sumber informasi baru yang menarik untuk pengolahan data. Twitter adalah jejaring sosial atau microblog yang memungkinkan penggunanya untuk mengirim dan membaca pesan berbasis teks hingga 280 karakter, yang dikenal dengan sebutan kicauan (tweet).

Twitter didirikan pada bulan maret 2006 oleh Jack Dorsey dan situs jejaring sosialnya diluncurkan pada bulan juli 2006. Twitter telah menjadi alat yang menarik bagi berbagai kalangan untuk mengikuti keinginan para pengguna terhadap setiap kondisi secara langsung. Hal ini menjadi sumber data yang potensial untuk digunakan oleh jutaan orang.

Dengan menggunakan Twitter banyak potensi promosi yang dapat diperoleh untuk kemajuan pariwisata daerah diantaranya adalah sebagai berikut:

a. Twitter merupakan media yang mampu meningkatkan sebuah brand reputation.

b. Banyak pengguna yang akan memiliki minat positif dengan hasil opini positif.

c. Twitter adalah social media marketing yang efektif.

d. Twitter dapat membentuk opini tentang brand images atau brand reputation suatu objek atau produk.

e. Twitter membawa antar pengguna untuk lebih dekat dalam berinteraksi dan saling berkomunikasi.

f. Para pengguna twitter dapat saling berbagi pengalaman dan pendapat atau opini.

(Dave, dkk. 2003) menyatakan bahwa Sentimen adalah informasi tekstual yang berada di dalam web dan berisi tentang fakta dan opini. Sentimen merupakan pernyataan subjektif yang mencerminkan persepsi seseorang terhadap suatu peristiwa. Terdapat penelitian lain yang disampaikan juga oleh (Kumar \& Sebastian, 2012) yang menyatakan bahwa sentiment analysis adalah studi komputasi yang berhubungan dengan pendapat dan berorientasi dengan pengolahan bahasa alami.

Penelitian dari (Jefry R, dkk., 2018) dengan judul "Peran Media Sosial Dalam Mendukung Pemasaran Produk Organisasi Bisnis" menjelaskan bahwa dengan analisis menggunakan metode kualitatif dengan pendekatan deskriptif eksploratif, artinya data yang diperoleh baik dari peneliti, informan 
kunci maupun data yang ada, kemudian dianalisa untuk mendapatkan hasil penelitian. Berikutnya, dari hasil penelitian tersebut diperoleh bahwa peran media sosial sangat membantu dalam memasarkan suatu produk dan dapat meningkatkan angka penjualan produk yang dipromosikan tersebut.

(E. Trihayuningtyas, dkk., 2018) pada penelitian dengan judul "Media Sosial Sebagai Sarana Informasi Dan Promosi Pariwisata Bagi Generasi Z Di Kabupaten Garut" menjelaskan bahwa hasil analisis yang dilakukan dengan menggunakan SPSS 21 menunjukkan media sosial merupakan sarana informasi dan promosi yang sangat sesuai untuk wisatawan generasi $\mathrm{Z}$ di bidang pariwisata. Oleh karena itu Dinas Pariwisata dan Kebudayaan Kabupaten Garut sebagai pembuat kebijakan harus dapat merangkul pasar wisatawan generasi $\mathrm{Z}$ dengan cara mempertimbangkan habitual mereka terhadap penggunaan media sosial.

\section{HASIL DAN PEMBAHASAN a. Analisis Data}

Pada penelitian ini, data yang digunakan ialah cuitan berbahasa Indonesia yang terdapat pada Twitter. Cuitan yang digunakan yang mengandung opini masyarakat Indonesia terhadap fasilitas dan pelayanan dari Museum Sangiran Kabupaten Sragen. Pemilihan data secara manual yaitu memilih kalimat-kalimat cuitan yang berbahasa Indonesia dan tidak mengandung gambar. Cuitan yang telah dipilih kemudian di simpan ke file excel. Data yang dibutuhkan dalam penelitian ini terdiri dari dua jenis, yaitu data latih dan data uji. Untuk kebutuhan latih, data yang berhasil dikumpulkan tersebut akan dikategorikan secara manual yang dilakukan oleh Penulis dan menilai sentimen yang terkandung di dalam cuitan tersebut dan menandai cuitan tersebut ke dalam tiga kategori sentimen yaitu cuitan yang mengandung sentimen negatif, sentimen positif dan sentimen netral.

\section{b. Analisis Pemrosesan Teks}

Pemrosesan teks merupakan proses menggali, mengolah, mengatur informasi dengan cara menganalisis hubungannya, aturan-aturan yang ada di data tekstual semi terstruktur atau tidak terstruktur. Untuk lebih efektif dalam proses pemrosesan dilakukan langkah transformasi data ke dalam suatu format yang memudahkan untuk kebutuhan pemakai. Proses ini disebut text prosessing. Setelah dalam bentuk yang lebih terstruktur dengan adanya proses diatas data dapat dijadikan sumber data yang dapat diolah lebih lanjut untuk dilakukan klasifikasi data atau teks yang sudah diolah.

Menurut (Zarrella, 2010) keberhasilan media sosial twitter sebagai media promosi adalah dengan melihat jumlah orang yang mengikuti sebuah akun pengguna. Jumlah ini merepresentasikan potensi jangkauan pemilik akun dan menunjukkan bagaimana kebanyakan daftar pengguna teratas biasanya diperingkat. Untuk tujuan pemasaran, jelas semakin banyak pengikut pada akun pengguna, semakin baik tetapi ini bukan satusatunya yang menjadi penentu keberhasilan dalam menyampaikan informasi sebagai promosi.

\section{c. Hasil Penelitian}

Menyiapkan data cuitan yang akan diolah dimana dalam penelitian ini data yang akan diolah yaitu data teks dari cuitan pada sosial media twitter yang berhubungan dengan Museum Purbakala Sangiran Kabupaten Sragen dengan mengandung kata 'sangiran'. Data tersebut dimasukkan ke dalam aplikasi pengolah angka file excel kemudian data tersebut diproses untuk diolah lebih lanjut. Selanjutnya tahap klasifikasi data cuitan yang sudah melalui tahap pemrosesan teks, data akan masuk ketahap klasifikasi untuk mengetahui dari data-data tersebut akan masuk atau terklasifikasikan ke dalam kategori sentimen positif, sentimen negatif atau sentimen netral.

Dari hasil akhir klasifikasi tersebut nantinya akan didapatkan hasil penelitian bahwa manfaat media sosial twitter sebagai media promosi pariwisata daerah cukup memiliki banyak manfaat. Karena media sosial khususnya twitter merupakan sarana untuk menyampaikan opini secara terbuka yang banyak digunakan oleh masyarakat. Banyaknya pengguna Twitter ini merupakan pangsa pasar potensial untuk menawarkan potensi pariwisata daerah agar dapat menarik minat masyarakat untuk berkunjung ke Museum Sangiran.

Dari pengamatan penelitian yang telah dilakukan, twitter adalah media promosi daring yang menguntungkan. Karena dengan 
twitter pengguna dapat menginformasikan potensi pariwisata daerah yang sedang ingin kenalkan kepada masyarakat luas. Twitter juga digunakan untuk mengetahui apa yang pengguna lain pikirkan mengenai promosi pariwisata yang dikenalkan sehingga dapat dijadikan masukan dan pembaharuan yang bisa segera diadaptasikan dalam promosi selanjutnya.

\section{PENUTUP}

\section{a. Kesimpulan}

Berdasarkan hasil analisis dan penelitian yang telah dilakukan pada Museum Sangiran, maka dapat diambil kesimpulan sebagai berikut :

1) Media sosial twitter merupakan salah satu media yang cukup efektif untuk dimanfaatkan sebagai media promosi khususnya untuk memperkenalkan pariwisata daerah.

2) Sangat interaktif, extensible messaging platform dengan API terbuka sehingga memudahkan penelitian dalam mengambil data.

3) Promosi melalui twitter dapat membantu meningkatkan brand images atau brand reputation apabila banyak informasi yang disampaikan bersifat positif.

4) Dengan memanfaatkan twitter tujuan promosi dari pariwisata daerah dapat tercapai untuk menarik minat masyarakat.

\section{b. Saran}

Penulis menyarankan pengembangan penelitian lebih lanjut sistem pengklasifikasian data atau cuitan dengan sentimen twitter sebagai berikut:

1) Peneliti menyarankan untuk penelitian selanjutnya untuk memberikan penambahan jumlah data latih dan data uji untuk mendapatkan hasil yang lebih baik saat klasifikasi cuitan.

2) Peneliti menyarankan untuk penelitian selanjutnya bahasa yang digunakan juga tidak hanya bahasa Indonesia tetapi dapat menggunakan bahasa daerah atau bahasa asing seperti bahasa inggris dan lainnya.

3) Peneliti menyarankan untuk penelitian selanjutnya pada tahap pemrosesan teks ditambah fitur stemming untuk mendapatkan hasil yang lebih baik

4) Peneliti menyarankan untuk penelitian selanjutnya tidak hanya dilakukan secara manual namun dapat menggunakan algoritma Nä̈ve Bayes Classifier, algoritma Support Vector Machine atau algoritma klasifikasi teks yang lainnya.

\section{REFERENSI}

Adam, C. K., Leong, C. H., \& Tou, H. (2002). Bayesian online classifiers for text classification and filtering. Proceedings of the 25th annual international ACM SIGIR conference on Research and development in information retrieval, 97-104.

Bifet, A., \& Frank, E. (2010). Sentiment Knowledge Discovery in Twitter. Proceedings of the 13th international conference on Discovery science (pp. 115). Berlin: Springer-Verlag.

Dave, K., Lawrence, S., \& Pennock, D. M. (2003). Mining the peanut gallery: Opinion extraction and semantic classification of product reviews. Proceedings of International $W W W$ Conference, 1- 3 .

E. Trihayuningtyas, W. Wulandari, Y. Adriani, Sarasvati. (2018). Media Sosial Sebagai Sarana Informasi Dan Promosi Pariwisata Bagi Generasi Z Di Kabupaten Garut. Tourism Scientifie Journal Vol.4 No.1.

Gurnelius, Susan. (2011). 30-minute Sosial Media Marketing: McGrawHill, US.

Kotler \& Amstrong. (2008). Prinsip-Prinsip Pemasaran 1. Jakarta: Erlangga.

Kumar, A., \& Sebastian, T. M. (2012). Sentiment Analysis: A Perspective on its Past, Present and Future. International Journal of Intelligent Systems and Applications, 1-2.

Jefry Romdonny, Maskarto Lucky Nara Rosmadi. (2018). Peran Media Sosial Dalam Mendukung Pemasaran Produk Organisasi Bisnis. IKRAITH EKONOMIKA. Vol 1 No 2.

Liu, B. (2011). Web Crawling. In Web Data Mining: Exploring Hyperlinks, Contents, and Usage Data. Chicago: Springer.

Mayfield, A. (2008, August 8). What is Social Media. Retrieved from iCrossing: http://www.iCrossing.com/ebooks

Nugroho, Fendy P. 2017. Implementasi Augmented Reality Technology (ART) Sebagai Media Promosi Tentang Museum Purbakala Sangiran Kabupaten Sragen. Yogyakarta: Universitas Amikom Yogyakarta. 
Jurnal INFORMA Politeknik Indonusa Surakarta p-ISSN : 2442-7942, e-ISSN 2716-5051

Vol. 6 Nomor 1 Juni 2020

Rosanti Utami Dewi S.Y dan Zam Zam Nurjaman. (2017). Penggunaan Jejaring Sosial Twitter Sebagai Media Promosi Pada Restoran Ranjang 69. Jurnal Komunikasi dan Media. Vol. 1 No.2 Februari 2017.

Zarella, Dan. (2011). The Social Media Marketing Book. Jakarta: Serambi. 